\title{
UPAYA PENCEGAHAN COVID-19 MELALUI PEMBAGIAN MASKER, HANDSANITIZER DAN PENYEMPROTAN DESINFEKTAN
}

\author{
Romadhiyana Kisno Saputri ${ }^{1^{*}}$, Moh. Kholil Mughofar ${ }^{2}$, Yogi Prana Izza ${ }^{3}$, Umma \\ Rohmawati ${ }^{4}$, Dimas Reza Fachrudin ${ }^{5}$ \\ ${ }^{1-5}$ Universitas Nahdlatul Ulama Sunan Giri Bojonegoro \\ Email Korespondensi: romadhiyana.ks@unugiri.ac.id \\ Disubmit: 01 Juli 2021 \\ Diterima: 06 Juli 2021 \\ DOI: https://doi.org/10.33024/jkpm.v5i2.4612
}

\begin{abstract}
ABSTRAK
Penyakit COVID-19 mudah menular sehingga dengan cepat bisa menjangkiti banyak. Pencegahan COVID-19 dapat dilakukan dengan rutin mencuci tangan dengan sabun dan atau handsanitizer, menggunakan masker dan menjaga jarak 1 meter. Untuk menjaga lingkungan bebas dari COVID-19 perlu dilakukan penyemprotan cairan desinfektan. Kegiatan pengabdian yang menggabungkan dua atau lebih upaya pencegahan COVID-19 belum banyak dilakukan, untuk itu, perlu adanya kegiatan pengabdian masyarakat dengan tema upaya pencegahan COVID-19 yang dilakukan melalui pembagian masker, handsanitizer serta penyemprotan desinfektan. Tujuan dari pengabdian maayarakat ini adalah untuk melakukan upaya pencegahan COVID19 dengan cara pembagian masker untuk memastikan warga menggunakan masker setiap keluar rumah, pembagian hand sanitizer serta penyemprotan desinfektan untuk memastikan rumah masyarakat tidak terkontaminasi virus penyebab COVID19. Mitra pengabdian masyarakat adalah warga desa Sambiroto Kecamatan Kapas Kabupaten Bojonegoro. Pelaksanaan pengabdian kepada masyarakat ini menggunakan metode pendidikan masyarakat yang dilakukan dalam bentuk sosialisasi penggunaan masker dan handsanitizer sekaligus pembagian 200 buah masker dan handsanitizer kepada warga RW 01 Desa Sambiroto Kecamatan Kapas Kabupaten Bojonegoro. Kegiatan pembagian masker dan handsanitizer dapat berhasil karena pemilihan metode yang tepat dan pelaksanaan yang optimal dengan adanya bantuan dan kerjasama dari pihak desa dan kepolisian. Kegiatan penyemprotan desinfektan dapat berhasil karena telah dilakukan di semua wilayah RW 01, baik di bangunan umum maupun di rumah pribadi warga dan juga adanya respon dan feedback positif dari warga. Untuk selanjutnya, penyemprotan desinfektan akan dilakukan secara berkala dan di seluruh wilayah desa.
\end{abstract}

Kata Kunci: Pencegahan COVID-19, Pembagian masker, Hand sanitizer, Penyemprotan desinfektan 


\begin{abstract}
COVID-19 diseases can easily spread so can quickly infect many people. Prevention of COVID-19 can be done by regularly washing hands with soap and/or hand sanitizer, using masks and maintaining a distance of 1 meter. To keep the environment free from COVID-19, it is necessary to spray disinfectant liquid. Community service activities that combine two or more COVID-19 prevention efforts have not been widely carried out, for this reason, community service activities with the theme of COVID-19 prevention efforts are carried out through the distribution of masks, hand sanitizers and spraying disinfectants. The purpose of this community service is make efforts to prevent COVID-19 by distributing masks, to ensure people use masks every time they leave the house, distributing hand sanitizers and spraying disinfectants to ensure people's homes are not contaminated with the virus that causes COVID-19. Community service partners are member of Sambiroto Village, Kapas District, Bojonegoro Regency. The implementation of this community service uses community education methods which are carried out in the form of socializing the use of masks and hand sanitizers as well as distributing 200 pieces masks and hand sanitizers to member of RW 01, Sambiroto Village, Kapas District, Bojonegoro Regency. The distribution of masks and hand sanitizers was successful because the selection method is right and the implementation is optimal with the help and cooperation of the village government and the police. The activity of spraying disinfectants was successful because it had been carried out in all areas of RW 01 , both in public buildings and in residents' private homes and there was also a positive response and feedback from residents. Henceforth, disinfectant spraying will be carried out periodically and throughout the village area.
\end{abstract}

Keywords: Prevention of COVID-19, Distributing Masks, Hand Sanitizer, Spraying Desinfectant

\title{
1. PENDAHULUAN
}

Pada awal bulan Maret 2020, beberapa warga Indonesia meninggal akibat penyakit menular yang disebabkan oleh virus, yaitu coronavirus disease 2019 atau COVID-19. COVID-19 merupakan penyakit infeksi disebabkan oleh virus SARS-CoV-2 dan menyerang sistem pernapasan (Meri et al., 2020). Penyakit COVID-19 mudah menular sehingga dengan cepat bisa menjangkiti banyak orang. Masyarakat dan pihak non-pemerintah diharapkan dapat berpartisipasi dalam pencegahan dan pengurangan risiko terpapar COVID-19 (Quyumi \& Alimansur, 2020). Pencegahan COVID-19 dapat dilakukan dengan rutin mencuci tangan dengan sabun, menggunakan masker yang menutup hidung dan mulut, menjaga jarak 1 meter atau menghindari interaksi fisik. Selain itu perlu tambahan upaya untuk menjaga lingkungan tetap bersih, sehat, dan bebas dari COVID-19 yaitu dengan melakukan penyemprotan cairan desinfektan (Musafira et al., 2020). Beberapa kegiatan telah diaplikasikan di masyarakat untuk pencegahan dan pengurangan risiko terpapar COVID-19, antara lain dengan pembagian masker, sabun pembersih tangan, hand sanitizer dan bahan pokok seperti beras (Candra et al., 2020). 
Desa Sambiroto merupakan salah satu desa di Kecamatan Kapas Kabupaten Bojonegoro. Desa ini memiliki titik pengeboran migas sehingga termasuk dalam desa kawasan migas sehingga menyumbang sumber pendapatan asli daerah terbesar di Kecamatan Kapas (Syahrizal, 2018). Berdasarkan hasil wawancara pada warga desa Sambiroto, dalam kehidupan sosial warga merasa ada masalah dengan timbulnya rasa curiga dan hilangnya kepercayaan terhadap orang-orang yang ada di seputaran warga pendatang atau yang baru warga kenal sejak awal pandemi COVID-19. Hal ini dikarenakan ketakutan warga terhadap penularan COVID-19 yang berasal dari warga pendatang atau yang baru warga kenal. Untuk menanggulangi permasalahan sosial yang terjadi dan pencegahan COVID-19, pemerintah desa Sambiroto telah melakukan upaya seperti edukasi pencegahan COVID-19 dan penyemprotan desinfektan di beberapa wilayah Desa. Namun, beberapa upaya harus tetap harus dilaksanakan mengingat jumlah kasus COVID19 di Kabupaten Bojonegoro yang masih cukup tinggi. Data kumulatif pasien COVID-19 di Kabupaten Bojonegoro mulai 1 Januari 2021 sampai awal bulan Maret 2021 menunjukkan ada 1226 orang terkonfirmasi positif, pasien sembuh sebanyak 1141, dan 37 pasien meninggal dunia, hak ini menunjukkan angka kematian karena COVID-19 sekitar 3\%, lebih tinggi dari angka nasional yaitu 2,7\% (Sasmito, 2021). Hal ini menunjukkan bahwa COVID-19 masih menjadi ancaman bagi warga Kabupaten Bojonegoro.

Beberapa kegiatan pengabdian kepada masyarakat untuk pencegahan COVID19 telah banyak dilakukan, antara lain kegiatan pencegahan COVID-19 yang dilakukan oleh Firdayanti, et al., (2020) melalui pembagian masker di Kelurahan Romang Polong Kabupaten Gowa yang menunjukkan hasil masyarakat patuh menggunakan masker terutama di pelayanan publik dan rumah ibadah serta menjaga jarak pada saat sholat berjamaah dilakukan. Kegiatan ini disambut antusias dan sangat bermanfaat bagi masyarakat. Kegiatan pemberdayaan masyarakat untuk pencegahan COVID-19 lainnya juga dilakukan oleh Wahyuni \& Putra (2020) di RW 5 Desa Gelam, Candi, Sidoarjo yang dilakukan dengan program penyemprotan desinfektan ke seluruh area RW 5, penyediaan alat cuci tangan, arahan tertulis pengurus RW, bantuan dana untuk warga terdampak COVID-19, yang menunjukkan hasil warga menjadi lebih waspada dan mematuhi anjuran pemerintah untuk jaga jarak, memakai masker dan cuci tangan dengan sabun. Kegiatan edukasi penggunaan hand sanitizer dan pembagian hand sanitizer disaat pandemi COVID-19 yang menunjukkan hasil masyarakat telah teredukasi akan pentingnya hidup bersih dan sehat guna menghindari penyebaran virus corona yang salah satunya dengan penggunaan handsanitizer (Fatmawati, 2020).

Penggunaan masker dalam upaya mencegah penularan Covid-19 sangat diperlukan. Demi menjaga ketersediaan masker masyarakat umum sangat dianjurkan memakai masker kain. Jenis masker kain yang dianjurkan adalah masker kain 3 lapis (Atmojo et al., 2020). Penggunaan antiseptik dan desinfektan efektif untuk mencegah penularan COVID-19. Antiseptik yang digunakan di masyarakat adalah sabun antiseptik dan hand sanitizer (Larasati et al., 2020). Kegiatan pengabdian yang menggabungkan dua atau lebih upaya pencegahan COVID-19 belum banyak dilakukan, padahal jika dilihat dari tingkat keberhasilan, setiap upaya yang telah dilakukan, semuanya berhasil mencegah penularan COVID-19. Untuk itu, perlu adanya kegiatan pengabdian masyarakat dengan tema upaya pencegahan COVID-19 yang dilakukan melalui pemberdayaan masyarakat 
dalam penggunaan dan pembagian masker, handsanitizer serta penyemprotan desinfektan. Tujuan dari pengabdian maayarakat ini adalah untuk melakukan upaya pencegahan COVID-19 dengan cara pembagian masker, handsanitizer untuk memastikan warga menggunakan masker setiap keluar rumah serta penyemprotan desinfektan untuk memastikan rumah masyarakat tidak terkontaminasi virus penyebab COVID-19.

\section{MASALAH}

Kabupaten Bojonegoro merupakan salah satu Kabupaten di provinsi Jawa timur yang memiliki angka kematian akibat COVID-19 diatas angka nasional. Kasus aktif pada 12 Maret 2021 masih 48 orang, sedangkan kasus suspect 174 orang. Kecamatan kapas termasuk zona merah dengan warga yang terkonfirmasi positif berjumlah 5 orang. Lokasi kegiatan pengabdian kepada masyarakat dan peta sebaran konfirmasi COVID-19 aktif dapat dilihat pada gambar 1 dan gambar 2 .

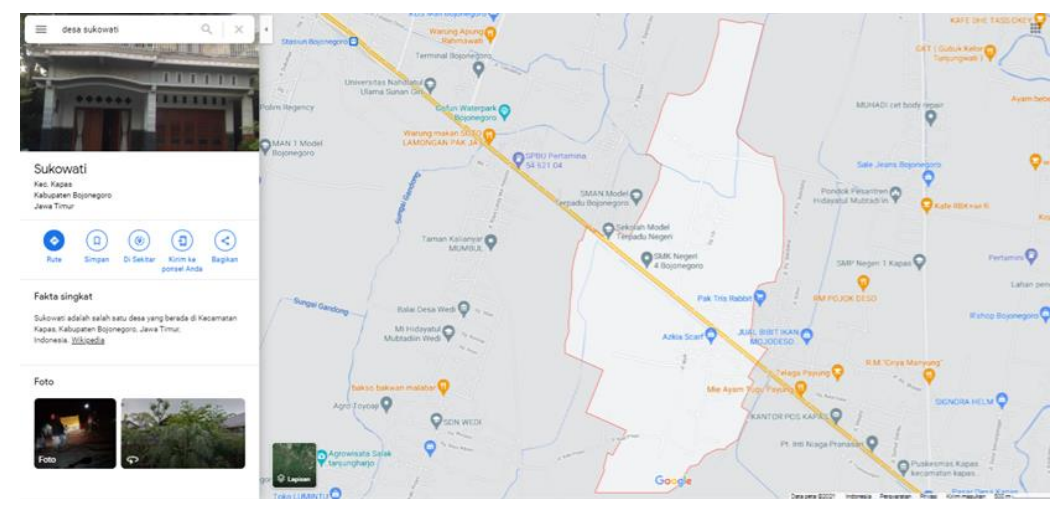

Gambar 1. Lokasi Kegiatan Pengabdian Kepada Masyarakat

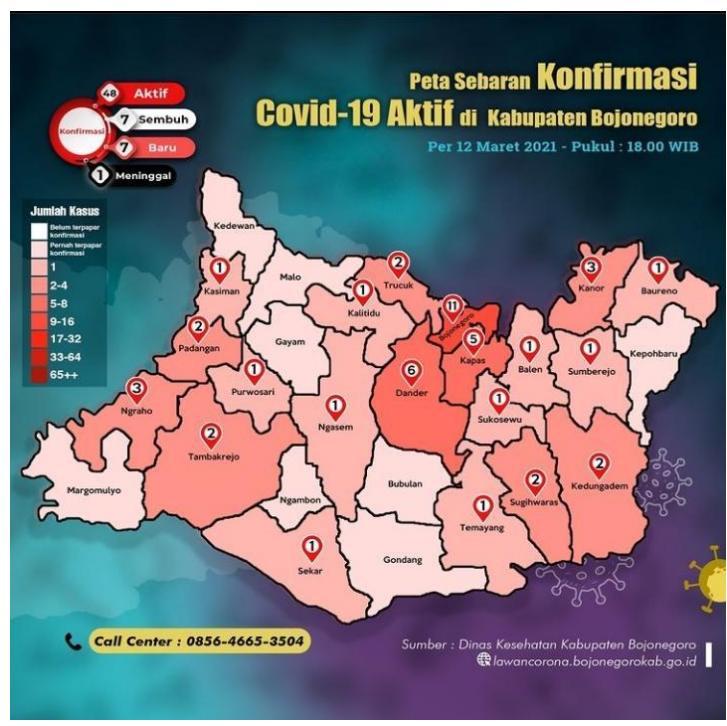

Gambar 2. Peta Sebaran Konfirmasi COVID-19 Aktif 


\section{METODE}

Kegiatan pengabdian kepada masyarakat dilakukan menggunakan metode pendidikan masyarakat. Upaya pencegahan COVID-19 dilakukan dengan dua kegiatan, kegiatan pertama adalah pendidikan masyakat yang dilakukan dalam bentuk sosialisasi penggunaan masker dan handsanitizer sekaligus pembagian masker dan handsanitizer secara gratis kepada semua kepala keluarga di RW 01 Desa Sambiroto Kecamatan Kapas. Kegiatan kedua adalah penyemprotan desinfektan di RW 01, khususnya di semua bangunan publik dengan didampingi perangkat desa dan warga Desa Sambiroto Kecamatan Kapas. Upaya pencegahan COVID-19 ini dilaksanakan bekerjasama dengan mahasiswa, pemerintah dan perangkat desa Sambiroto pada hari Senin 19 Maret 2021. Kegiatan ini dilakukan secara door to door, sehingga tidak ada kerumunan.

\section{HASIL DAN PEMBAHASAN}

Program pengabdian kepada masyarakat ini diharapkan dapat membantu masyarakat dalam upaya pencegahan COVID-19, khususnya masyarakat desa Sambiroto Kecamatan Kapas Kabupaten Bojonegoro. Kegiatan ini melibatkan berbagai pihak demi tercapainya tujuan bersama dan berharap seluruh masyarakat merasakan manfaat dari kegiatan ini. Kegiatan sosialisasi penggunaan masker dan handsanitizer sekaligus pembagian masker dan handsanitizer secara gratis dilakukan di wilayah RW 01 Desa Sambiroto Kecamatan Kapas Kabupaten Bojonegoro dengan cara mendatangi rumah masingmasing keluarga. Kegiatan ini dapat terlaksana dengan baik dengan dukungan dan bantuan dari pemerintah desa dan kepolisian. Kegiatan ini mendapatkan respon positif dari warga, semua warga RW 01 Desa Sambiroto Kecamatan Kapas Kabupaten Bojonegoro menerima dan menggunakan masker serta handsanitizer yang dibagikan secara tepat. Setiap warga yang keluar rumah yang tidak memakai masker, akan memakai masker yang telah dibagikan. Hal ini menunjukkan keberhasilan program, program ini selain mampu mendukung keberhasilan upaya pencegahan COVID-19, juga mampu mengurangi masalah sosial yang ada di Desa Sambiroto pada awal pandemi, yaitu rasa curiga pada pendatang atau orang baru. Masker yang dibagikan merupakan masker kain yang dapat dicuci sehingga dapat digunakan beberapa kali. Pendidikan yang diberikan dilakukan dengan sosialisai secara door to door pada tiap rumah lebih efektif untuk meningkatkan pengetahuan masyarakat. Kegiatan pengabdian yang dilakukan oleh Wardhani \& Azhar, (2020), menunjukkan kegiatan sosialisasi secara door to door kepada masyarakat yang disertai dengan pemahaman dan pembagian masker telah mencapai target untuk mengurangi penyebaran COVID19. Pembagian masker juga dilakukan oleh Sembiring \& Suryani (2020) yang menunjukkan dengan melakukan pembagian masker dapat mengurangi jumlah warga yang tidak menggunakan masker saat keluar rumah, karena masker yang dibagikan, dapat langsung digunakan. Kegiatan pembagian masker dan handsanitizer dapat berhasil karena pemilihan metode yang tepat dan pelaksanaan yang optimal dengan adanya bantuan dan kerjasama dari pihak desa dan kepolisian. 


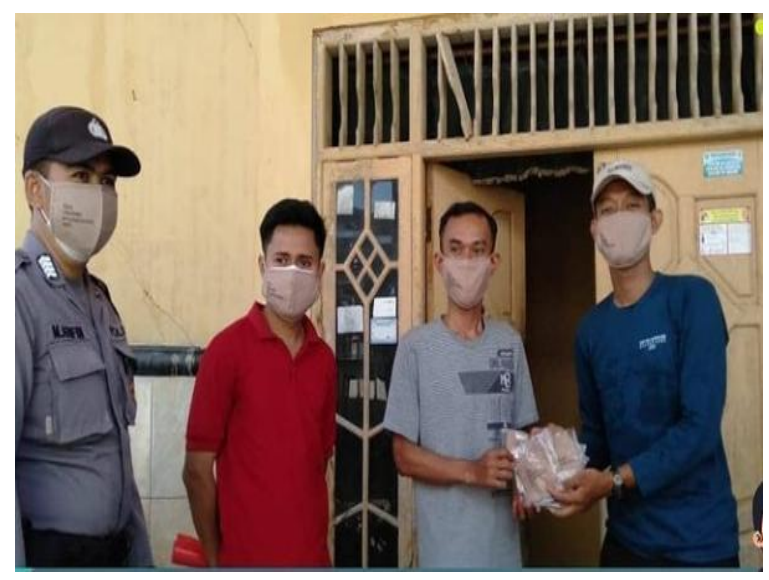

\section{Gambar 3. Pembagian Masker dan Handsanitizer kepada Warga Didampingi} oleh Pihak Desa dan Kepolisian

Kegiatan kedua adalah penyemprotan desinfektan. Kegiatan ini bertujuan untuk menjaga kebersihan ruangan dari virus, khususnya virus penyebab COVID19. Penyemprotan desinfektan dilakukan khususnya di tempat-tempat umum seperti sekolah, masjid dan warung dan rumah warga RW 01 secara umum. Kegiatan ini mendapatkan respon yang positif dari semua warga, termasuk pengurus masjid dan pihak sekolah yang dapat dilihat dari kejadian dimana ada masjid yang baru dibersihkan, lalu dilakukan penyemprotan desinfektan yang menyebabkan pengurus masjid membersihkan ulang masjid, namun pengurus justru berterimakasih karena telah dilakukan penyemprotan di masjid. Penyemprotan cairan desinfektan dilakukan untuk membantu masyarakat membersihan lingkungan rumah dari paparan virus. Virus corona bersifat sangat sensitive terhadap panas dan secara efektif dapat dinonaktifkan oleh desinfektan. Desinfeksi secara rutin perlu dilakukan untuk mencegah penyebaran virus penyebab COVID-19. Hal ini sejalan dengan kegiatan pengabdian kepada masyarakat yang dilakukan oleh Ertiana et al., (2020), yang menunjukkan pencegahan COVID-19 dapat dilakukan dengan peningkatan peran serta masyarakat pada kegiatan penyemprotan desinfektan secara berkala oleh masyarakat. Pencegahan penularan COVID-19 salah satunya dengan penyemprotan desinfektan di tempat yang sering dikunjungi orang banyak atau tempat umum karena disinfektan dapat membunuh seluruh virus 100\% (Zulkifri \& Ashar, 2020). Desinfektan merupakan zat yang mengandung glutaraldehid dan formaldehid dan dapat membunuh patogen lingkungan. Penggunaan desinfektan di bawah tanggungjawab tenaga medis, namun untuk sekarang penggunaan desinfektan tidak hanya di rumah sakit, namun di rumah juga sering digunakan. Penggunaan desinfektan efektif untuk membunuh virus, namun tetap perlu diikuti dengan pelaknsanaan protokol kesehatan, yaitu memakai masker, mencuci tangan dengan sabun atau menggunakan handsanitizer dan menjaga jarak (Larasati et al., 2020). Kegiatan penyemprotan desinfektan dapat berhasil karena telah dilakukan di semua wilayah RW 01, baik di bangunan umum maupun di rumah pribadi warga dan juga adanya respon dan feedback positif dari warga. Untuk selanjutnya, penyemprotan desinfektan akan dilakukan secara berkala dan di seluruh wilayah desa. 


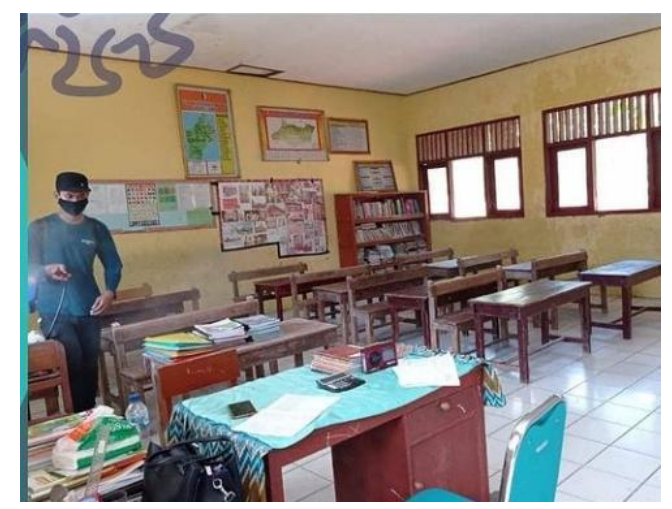

Gambar 4. Penyemprotan Desinfektan di Sekolah

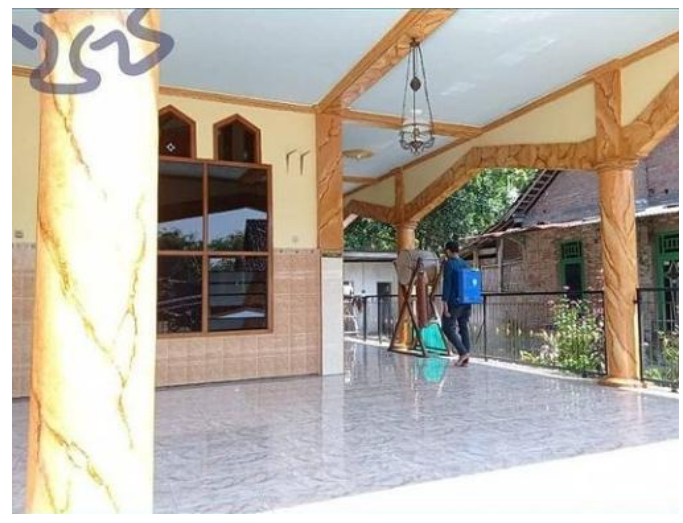

Gambar 5. Penyemprotan Desinfektan di Masjid

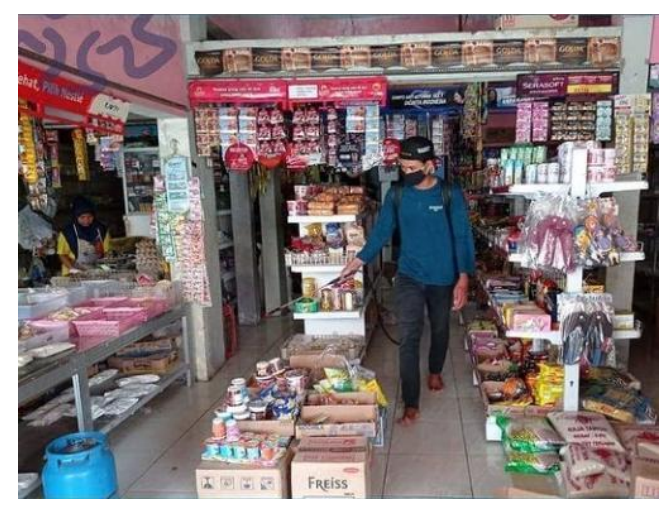

Gambar 6. Penyemprotan Desinfektan di Warung 


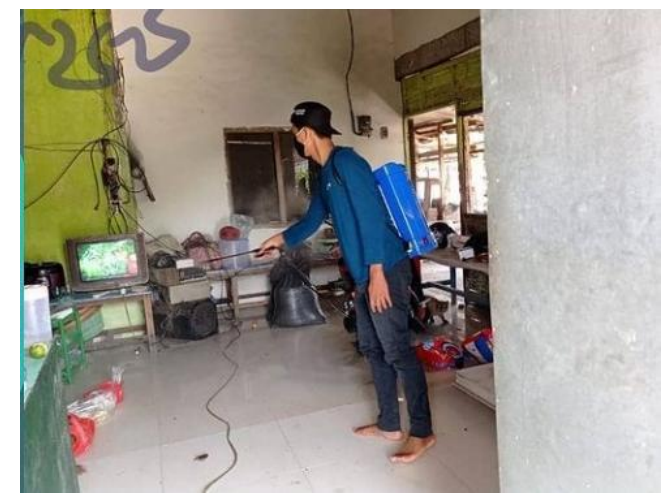

Gambar 7. Penyemprotan Desinfektan di Rumah Warga

\section{KESIMPULAN}

Pelaksanaan pengabdian kepada masyarakat ini menggunakan metode pendidikan masyarakat yang dilakukan dalam bentuk sosialisasi penggunaan masker dan hand sanitizer sekaligus pembagian masker dan hand sanitizer kepada warga RW 01 Desa Sambiroto Kecamatan Kapas Kabupaten Bojonegoro. Kegiatan pembagian masker dan handsanitizer dapat berhasil karena pemilihan metode yang tepat dan pelaksanaan yang optimal dengan adanya bantuan dan kerjasama dari pihak desa dan kepolisian. Kegiatan penyemprotan desinfektan dapat berhasil karena telah dilakukan di semua wilayah RW 01, baik di bangunan umum maupun di rumah pribadi warga dan juga adanya respon dan feedback positif dari warga. Untuk selanjutnya, penyemprotan desinfektan akan dilakukan secara berkala dan di seluruh wilayah desa.

\section{DAFTAR PUSTAKA}

Atmojo, joko tri, Iswahyuni, S., Rejo, \& Setyorini, C. (2020). Penggunaan Masker Dalam Pencegahan Dan Penanganan Covid-19. Penggunaan Masker Dalam Pencegahan Dan Penanganan Covid-19: Rasionalitas, Efektivitas, Dan Isu Terkini, 3(2), 84-95.

Candra, A. I., Santoso, S., Hendy, H., Ajiono, R., \& Nursandah, F. (2020). Upaya Pencegahan Penyebaran Virus Covid-19 Di Kelurahan Lirboyo Kota Kediri. Jurnal Ilmiah Pangabdhi, $\quad 6(2), \quad 150-153$. https: / /doi.org/10.21107/pangabdhi.v6i2.7395

Ertiana, D., Ulfa, M., Aspiyani, A., Silaturrokhmah, S., \& Prastiwi, N. W. Y. (2020). Peningkatan Peran Serta Masyarakat Dalam Pencegahan Covid-19 di Desa Maduretno Kecamatan Papar Kabupaten Kediri. Darmabakti : Jurnal Pengabdian Dan Pemberdayaan Masyarakat, 1(2), 23-33. https: / /doi.org/10.31102/darmabakti.2020.1.2.23-33

Fatmawati, F. (2020). Edukasi Penggunaan Hand Sanitizer Dan Pembagian Hand Sanitizer Disaat Pandemi Covid-19. JCES (Journal of Character Education Society), $3(2)$, 432-438. http://journal.ummat.ac.id/index.php/JCES/article/view/2401

Firdayanti, Anieq, M., Ferawati, T., Zelna, Y., Sitti, S., \& A Dian. (2020). Jurnal 
Abdimas Kesehatan Perintis Pencegahan Covid-19 Melalui Pembagian Masker Di Kelurahan Romang Polong Kabupaten Gowa. Jurnal Abdimas Kesehatan Perintis, 2(1), 53-57.

Larasati, A. L., Gozali, D., \& Haribowo, C. (2020). Penggunaan Desinfektan dan Antiseptik Pada Pencegahan Penularan Covid-19 di Masyarakat. Majalah Farmasetika, 5(3), https://doi.org/10.24198/mfarmasetika.v5i3.27066

137-145.

Meri, Khusnul, Suhartati, R., Mardiana, U., \& Nurpalah, R. (2020). Pemberdayaan Masyarakat dalam Penggunaan Handsanitiser dan Masker sebagai Upaya Preventif terhadap COVID-19. Bantenese Jurnal Pengabdian Masyarakat, 2(1), 26-33.

Musafira, Fardinah, Qardini, L., Fatimah, M. F., Ardiputra, S., \& Asrirawan. (2020). Edukasi pembuatan dan penyemprotan desinfektan pada masyarakat di desa suruang kecamatan campalagian kabupaten polewali mandar. Communnity Development Journal, 1(3), 416-421.

Quyumi, E., \& Alimansur, M. (2020). Upaya Pencegahan Dengan Kepatuhan Dalam Pencegahan Penularan Covid-19 Pada Relawan Covid. Jph Recode, 4(1), 8187.

Sembiring, R., \& Suryani, D. E. (2020). Sosialisasi Penerapan Protokol Kesehatan di Masa Pandemi dengan Pembagian Masker Kesehatan kepada Para Pedagang dan Pengunjung Pasar Tradisional Paak Sore Padang Bulan. Jurnal Abdimas Mutiara, !(2), 124-130.

Syahrizal, A. (2018). Strategi Optimalisasi Pengelolaan Kekayaan (Aset) Desa Dalam Pembangunan Desa (Studi Kasus Di Desa Sambiroto Kecamatan Kapas Kabupaten Bojonegoro). Publika, 6(4).

Wahyuni, H. C., \& Putra, B. I. (2020). Pola Pemberdayaan Masyarakat Untuk Mencegah Penyebaran COVID-19 di RW 5 Desa Gelam, Candi, Sidoarjo. Prosiding SEMADIF, 1, 498-503. http://semadif.flipmaslegowo.org/index.php/semadif/article/view/104

Wardhani, L. D. K., \& Azhar, A. P. N. (2020). Sosialisasi dan Pembagian Masker Sebagai Upaya Preventif Terhadap Covid-19 Di Lingkungan Magersari Serang Banten. ... : Jurnal Pengabdian Pada Masyarakat, 1, 45-51. https: //www.ejournal.my.id/atjpm/article/view/398

Zulkifri, A., \& Ashar, Y. (2020). Dampak Cairan Disinfektan Terhadap Kulit Tim Penyemprot Gugus Tugas Covid-19 Kota Binjai. Jurnal Menara Medika, 3(1), 7-14. https: //eresources.perpusnas.go.id:2125/media/publications/326196-hubunganpengetahuan-tentang-kesehatan-r-0e91516f.pdf 